\title{
What Comes after "Post-Soviet" in Russian Studies?
}

\section{Citation}

Buckler, Julie A. 2009. What comes after "Post-Soviet" in Russian studies? PMLA 124(1): 251-263.

\section{Published Version}

doi:10.1632/pmla.2009.124.1.251

\section{Permanent link}

http://nrs.harvard.edu/urn-3:HUL.InstRepos:4341694

\section{Terms of Use}

This article was downloaded from Harvard University's DASH repository, and is made available under the terms and conditions applicable to Other Posted Material, as set forth at http:// nrs.harvard.edu/urn-3:HUL.InstRepos:dash.current.terms-of-use\#LAA

\section{Share Your Story}

The Harvard community has made this article openly available.

Please share how this access benefits you. Submit a story.

Accessibility 


\section{What Comes after "Post-Soviet" in Russian Studies?}

\section{RUSSIAN STUDIES ARE STILL IN LOVE WITH THEIR FASCINATING AND UN-}

\section{PREDICTABLE SUBJECT, DESPITE RADICALLY CHANGING GEOPOLITICAL}

realities and shifts in the academic climate. We in the field have been through something resembling the free-market shock therapy prescribed for newly non-Soviet Russia, a major shake-up in intellectual orientation and logistics. Our methodologies, perspectives, and projects are always in this sense a reflection of our present-day subject, but they are also a self-portrait, the latest in a series. ${ }^{1}$

Since the Russian Revolution of 1917, Western scholars of Russia have variously characterized the imperial era, but they have nearly always viewed the past as prefiguring the (Soviet or post-Soviet) present, casting the present moment as overdetermined. The censorship and repression of the imperial period seemingly rendered inevitable the violations of human rights during the Soviet period. In the immediate aftermath of 1991, Western specialists focused on the end of the imperial period, on nascent capitalism and commercial culture, finding Russia to have been much more like us than we had imagined, our affinity with it interrupted by seventy-plus years of Soviet rule and restored in the cultural climate of post-Soviet Russia.

How do Russian studies make sense now, after the cold war, in the larger context of globalization? Does the discourse on postcolonialism apply in our case? Has the "post-Soviet" moment come and gone?

\section{Where Have We Been All These Years?}

Just as Soviet citizens were used to paying unchanging prices for basic items-a loaf of bread, a metro token-scholars of Russian literature and culture in the United States long relied on seeming constants in their professional and intellectual lives. One disciplinary truism held that literature in repressive nineteenth-century Russia compensated for the lack of a developed "public sphere" and provided a forum for debating social and political issues. ${ }^{2}$ The tenets of socialist realism made literature no less central, casting state writers
JULIE A. BUCKLER, professor of Slavic languages and literatures at Harvard University, is the author of Mapping St. Petersburg: Imperial Text and Cityshape (Princeton UP, 2005). Her current project is titled "Cultural Properties: The Afterlife of the Imperial in Soviet and Post-Soviet Russia." 
as "engineers of the human soul." 3 The much mythologized dissenting Russian writer and the idealized Russian-intelligentsia reader were a matched pair, willing to risk life for the sake of literature and its truth-telling mission (Todd, "Russian Literature" 31-32).

The "Aesopian language" of nineteenthcentury Russian literature gradually evolved into the complex intertextuality of the twentieth century, a code known to insiders and specialists. Literature was accorded special status as the only discourse sophisticated and elusive enough to convey dangerous essential meanings and preserve them for future generations. Products (by birth or training) of a cultural context that so elevated literature's role, Russian-literature specialists in the United States devoted themselves to studying, publishing, and translating endangered texts, creating a canon counter to the official literary canon of the Soviet Union (Emerson, "Slavic Studies" 450). It has been remarked more than once that the iron curtain separated us from our counterparts in other American humanities departments, but that selfsame curtain also drew us (literary specialists and historians in particular) into a vivid, multidisciplinary area-studies constellation (Steiner; see also Clark, "Beyond the Wall").

By the end of 1991, the Soviet Union had dissolved and the former republics declared their independence, the Russian republic among the first. For Russian specialists too, our reality became history, and it seemed that our present was comprehensible only as aftermath. Area studies in general have suffered decline and downsizing, but Soviet and post-Soviet studies were particularly hard-hit, and the historical, geopolitical, and cultural Russo-centrism of what remains has been subjected to sharp internal critique by scholars of Ukraine and Belarus, central and southeastern Europe, and central Asia. Russian-not to mention Polish, Czech, and Ukrainianliterary studies in the twenty-first-century Anglo-American academy must now contend with the seeming nineteenth-century romantic quaintness of national language and literature programs (Platt 209). But studying these literatures, at least for American specialists, was not simply a project of nationalist selfcelebration, since our purpose arose from the importance of literature, both demonstrated and perceived, in the sociopolitical environment of modern Russia. After 1991, it became easier for scholars to obtain visas to Russia, but the rising cost of books in the new Russia (not to mention the lack of time to read them) made literature seem more a luxury than a moral and spiritual necessity. Thus, scholars exploring the rampant post-Soviet nostalgia in Russia themselves harbor a complicated mix of feelings toward the Soviet past.

A newly skeptical awareness of literature's function in the larger cultural contexts of imperial, Soviet, and post-Soviet Russia has overtaken us. Recent studies of readership examine the wishful aspects of the familiar mythology: the reading public as a construct, a fantasy created by the intelligentsia and the government in curious collaboration. When the government controlled publication, print runs, and dissemination, books became a permanently scarce commodity, even a fetish, objects of desire for Soviet readers, who avidly collected and displayed them (in pursuit of "complete collected works" to adorn living room bookshelves [Lovell]). The dominance of state production as well as the valorization of anything "unofficial" made it difficult to identify readers' tastes during the Soviet period, whereas in the post-Soviet era we are faced with an explosion of diverse reading matter and a proliferation of small private publishers, a situation harking back in many respects to the late imperial years.

The culturally privileged position of writers in Russia and across the former Soviet bloc has succumbed to the changing literary marketplace, and these present conditions also provoke us to reevaluate the past (Wachtel). Russian literary specialists have become 
more self-conscious about the construction and perpetuation of the giant-writer cults (Pushkin, Tolstoy) so dominant in modern Russian cultural history. ${ }^{4}$ The practices governing the formation of official and unofficial literary canons have come under increasing scrutiny, as has the pervasive presence of the political in the Russian literary sphere. Kathleen Parthé examines the tradition of producing and distributing texts outside official channels as well as Russian readers' compulsive search for subversive messages in artistic works. Parthé's study urges a more nuanced approach to samizdat, or self-published literature (not always artistic or dangerous) and to officially published work (not always fully in support of state ideology or policy). She brings into relief ten historically powerful "beliefs" about literature in Russia, among these that Russians read more than any other people and that literature formed national identity in Russia. Related to these beliefs is the notion that censorship in Russia produced a particularly sensitive and receptive reader whose imagination was stimulated by the search for hidden meanings (Holquist 14). This complex of literature-centered beliefs, mythologies, and practices seems unlikely to survive in the post-Soviet cultural climate.

Topics have been deheroicized; terms are no longer absolute. In a 1998 survey of the state of the field, William Mills Todd III notes a shift from a centripetal model of literature-“whether this 'center' consists in the agency of a heroic author, the seriousness of the reading public, the malevolence of the censor, the power of the canon, the importance of the questions this literature raises, or the appropriation of literature by a central government or ideology"-to a decentered and chaotic centrifugal one, in which the importance literature seemed to have is in question and official literary institutions are in disarray ("Russian Literature" 31-34).

By the 1980s, we had to a great extent abandoned our disciplinary conviction that the study of literature was a science, and the work of structuralist theorists such as Roman Jakobson pointed the way beyond our traditional philological and textological focus toward discourse and cultural studies. We now look to a more diverse set of theoretical and disciplinary frameworks, past our adored Russian formalists, Prague structuralists, Bakhtin circle, and Moscow-Tartu cultural semioticians.

We are searching for new ways to understand historical periods, social formations, and artistic genres, beyond the boundedness of our old paradigms. Jehanne Gheith, for example, addresses the absence of major nineteenthcentury prose-writing women in the Russian literary canon. Why was there no Russian Jane Austen or Madame de Staël, no Russian Brontës, George Sand, George Eliot, or Virginia Woolf? In a manner that bears directly on canon formation, Gheith investigates the politics of producing scholarly editions, complete collected works, and translations, as well as the lower prestige accorded literary forms, such as autobiography and novella, that women writers chose more often than the novel and short story. Similarly, in my book Mapping St. Petersburg I argue that the vaunted and purportedly dominant "neoclassical style" of imperial Saint Petersburg was an insistent fantasy that lingered from the time of the Napoleonic wars through the Soviet period. This "neoclassical" orientation masked a perverse blindness to the diversely eclectic architectural structures built during the final century of the czarist era and to all they implied about changing demographics and tastes.

This new attention to cultural blind spots and to creative forms of accommodation counterbalances the longstanding disease of binarism in Russian studies, possibly a function of the notorious and leveling thesis elaborated by the semioticians Yury Lotman and Boris Uspensky, according to which binarism is one of the defining qualities of Russian culture (31-33). But it is not easy to get beyond the crude and limiting contrasting notions of 
official and dissident, Slavophile and Westernizer, art and politics, imperial and Soviet, Soviet and post-Soviet. A true embrace of the middle ground would require us to give up many of these cherished dichotomies.

\section{Not Whither Russia, but Why Russia? Why Russia?}

The nineteenth-century poet Fyodor Tyutchev asserted that Russia cannot be grasped with the mind (“Умом Россию не понять"). Winston Churchill termed Russia "a riddle wrapped in a mystery inside an enigma” (403). Is Russia ultimately, despite Western influences on an elite minority, an Eastern-style culture, a representative of the antimodern "Oriental despotism" (Malia 6), even in its Soviet incarnation? Or is Russia's purported uniqueness a product of its identity as hybrid of East and West (Schenker)? Or is the Russian case just one among many trajectories of modernization, an alternative passage through industrial revolution, mass literacy, and secularization (Engelstein, "New Thinking" 496)?

Some scholars interrogate Russia's assignment to the easternmost point of the West-East cultural gradient, arguing that the West constructed its myth of Russia as a locus of oriental despotism or a magnificent "primitive" power (Malia). For others, the very conviction that Russia has an independent cultural and historical tradition sets it apart from the West (McDaniel). Russian thinkers in the nineteenth and twentieth centuries, among them Fyodor Dostoyevsky and Nikolay Berdyayev, asserted that Russia's destiny was to transform human society into an Orthodox Christian community, countering the Western emphasis on science and the rule of law. One could also contend, as Marshall Poe does, that real historical factors set Russia apart, such that Russia is best understood as "culturally sui generis and historically distinct" (xii). From this perspective, Russia is not an eternal failure but rather the only non-Western power to defend itself against Western imperialism for centuries, a powerful state that represented the only non-Western path to modern society.

Will we continue to subscribe to the old myth of Russian exceptionalism or posit new affinities? We might now see Russia as parallel to America, in a revisionist account of the cold war or in broader historical terms of emerging national consciousness. Some have compared the traditions of Russian and African American cultural nationalism, placing them in the context of a dominant Western narrative of world civilization that relegated Slavs and African Americans to the status of nonhistorical peoples. Dale Peterson invokes W. E. B. DuBois's notion of "double-consciousness"-whereby an oppressed segment of society views itself simultaneously through its own eyes and through the internalized standards of a dominant culture-to explore the writings of Pyotr Chaadayev, Alexander Crummell, Dostoyevsky, Zora Neale Hurston, Charles Chesnutt, Ivan Turgenev, Ralph Ellison, Richard Wright, Maksim Gorky, and Gloria Naylor. Susan Buck-Morss sees the American and Soviet mass utopias as moved, respectively, by consumerism and communism, linked by their abuses of state power and by the common utopian dream that mass sovereignty combined with mass production would create complete social harmony. From this perspective, the end of the cold war was less a victory of one side than the dissolution of two intertwined political imaginaries.

The projects of inventing, imagining, constructing, and performing Russianness have been subjected to vigorous scrutiny. Indeed, the notion of Russianness is always already fissured. As the proverb goes, referring to the Mongol invasion and subjugation of Kievan Rus in the thirteenth century, "Scratch a Russian, find a Tatar." This proverb could be amended today as "Scratch a Russian, find a Balt, non-Russian eastern Slav, Jew. ..." Gabriella Safran examines stories of Jewish assimi- 
lation and conversion by four writers of three ethnicities and religions, living in four parts of the Russian Empire and writing in two languages, to uncover an assimilation discourse caught between Enlightenment universalism and Romantic essentialism. In a revisionist approach to a nearly sacred subject, scholars have explored the significance of the Russian national poet Pushkin's partially African heritage (Nepomnyashchy, Svobodny, and Trigos).

If Russianness is not considered in ethnic or linguistic or even national-cultural terms, it might be defined more broadly as a kind of attitude, a bold anticapitalist revolutionary avant-gardism that rejects dominant Western paradigms (Marks). This attitude can be seen in the inspirational influence of Russian artistic forms on the modern world or as a terrifying antirational, anarchic-utopian nihilism, a transfer of the old sectarian paradigm (going out in a blaze of glory) to a secular and political landscape. Alternatively, we could follow Mikhail Epstein in seeing Russia as "the largest ordinary place in the world" ("Transculture" 111).

Russian is still the lingua franca of the former republics, and Russia is still at the center of historical narratives that cover a vast territory. But Russia cannot stand "synechdochically ... for the entire ... heterogeneous and pluricultural world of Slavs," as Russia's nineteenth-century Pan-Slavists wished (Kujundzic 5). Similarly, Russia was (and still is) falsely conflated with the Soviet Union and even the Soviet bloc, a view that reflects a superficial knowledge of the diversity of cultures there and that unwittingly endorses the official Soviet expectation of eventual cultural homogenization (von Hagen). ${ }^{5}$

Is it still possible to apply the discourse of imperialism, in which Russia always manifests imperialist behavior, whether in its czarist, Soviet, or post-Soviet guises? ${ }^{6}$ In fact, the multiethnic dimensions of the territory encompassed by Russian studies map poorly onto more familiar Western models. Imperial Russia was not a nation-state where geopo- litical and ethno-cultural boundaries coincided neatly but a multiethnic, multilingual entity with a dominant Slavic population and culture (Kappeler). Russian colonialism in central and eastern Europe, Siberia, the Caucasus, central Asia, and the Far East relied on contiguous expansion rather than overseas conquest (Thompson; see also Chernetsky, Condee, Ram, and Spivak). Russian colonial rule tended, moreover, to be based on military might, not power and knowledge, and lacked a philosophical stance to justify its conquests as civilizing missions. Finland, the Baltic provinces, Poland, Ukraine, Georgia, and Armenia (the nations on the western and southwestern edges of the Russian empire) long felt more civilized than Russia, and the above-mentioned western white colonies saw themselves as occupied rather than colonized. Russian subjects were, moreover, deprived of the same rights denied to subalterns or to groups such as Jews and ethnic Germans living in Russia. All these factors help to explain why the vast territory of the post-Soviet sphere (now encompassing twenty-seven countries) has received so little attention in the Western discourse of postcolonialism (Moore).

How can an object of study be defined without satisfactory terms? Sovietology is now "transitology" or "post-Sovietology." We study the "territory formerly known as the Soviet Union" or the "former Soviet Union" (FSU), the "Newly Independent States" (NIS), or, more generally, the "postsocialist" or "postcommunist" world. Should we speak of eastern Europe, central Europe, or east-central Europe (Wolff)? The Balkans or southeastern Europe (Todorova)? Central Asia or the Middle East? Conflating Russian and Slavic is a surefire way to make enemies, but even Slavic doesn't begin to cover the territory (Clark, "Beyond the Wall" 2; see also Verdery). Slavic includes Russia, Ukraine, Belarus, Poland, the Czech Republic, Slovakia, Slovenia, Croatia, Serbia, Bulgaria, and Macedonia but does not account for Albania, Estonia, Latvia, Lithuania, 
Hungary, Romania, Moldova, Georgia, Armenia, Kazakhstan, Kyrgystan, Tajikistan, Turkestan, and Uzbekistan. How about "Russian and Eurasian" or just "Eurasian"?

Eurasia is one of the most common emerging designations for the region, termed an antiparadigm and thus not to be confused with xenophobic or neoimperialist Eurasianist paradigms in contemporary or historical incarnations (von Hagen). This newly conceived Eurasia offers an alternative to viewing histories of the region according to the nation-state model of modern western Europe and instead emphasizes the interactions among empires (Mongolian, Byzantine, Iranian, Chinese, Ottoman) in central Eurasia. Scholars are giving new attention to the borderlands of empires, where economic and cultural interchanges occur, as well as to regional histories and diasporas. The study of wars-Napoleonic, Caucasian, Crimean, Russo-Turkish, RussoJapanese, World War I, World War II-with their resultant mobility and mixing, has also been revitalized. Scholars seek now to incorporate Eurasia into world history and to move away from separatist, exceptionalist accounts. But can there be a post- or antiparadigmatic way of thinking and writing about Russia, a baffling cultural space that seems to demand recourse to such models while simultaneously resisting their imposition (Engelstein, "Paradigms" 876-77)? Perhaps shifting our scrutiny from political structures and perceived unities to cultural phenomena might provide a more flexible basis for analysis.

\section{Increasingly Popular Culture}

The "fall" of the Soviet Union signaled the decline of Russian high culture as the unquestioned object of hushed veneration and the concomitant slide of the imperial-era Russian intelligentsia-politically and socially progressive but in many ways culturally conservativefrom its place as the sole arbiter of taste and value. A wave of scholarly attention to popular culture revealed the late czarist cultural landscape to be gloriously plural, a heterogeneous space for diverse social interactions and modern patterns of living among the emerging urban middle class. ${ }^{8}$ Even so-called mass culture under Stalin-cultural production created, promoted, financed, and distributed by the Soviet state-can be seen as a form of popular culture, since the Soviet public creatively consumed it through a range of strategies. As it turns out, the Soviet monolith also gave rise to the popular stuff of everyday diversion, to detective novels and science fiction, jokes and songs, films for the general audience, radio and television, and the variety stage (Stites, Culture and Russian Popular Culture).

Contemporary post-Soviet Russia offers an irresistible field for popular culture studies, with its mixture of prerevolutionary elite markers (Empire-style home furnishings for wealthy "new Russians"), and Soviet artifacts (Communist kitsch [Barker]). The post-Soviet moment recalls the late czarist moment, as well as the Petrine era and its eighteenthcentury aftermath, all periods when Western influences, fashions, and lexicons flowed rapidly and indiscriminately into the Russian cultural sphere and were then adapted to the local environment. Anthony Olcott thus sees the booming native subgenre of detective fiction in the 1990s as reflecting Russian perceptions of law, crime, guilt, and justice quite unlike those dominant in the West, a response to the post-Soviet cultural climate.

Western methodologies for cultural studies, however, have not been among those rapidly flowing influences, at least not until recently. The Anglo-American model of cultural studies, with its revisionist Marxist approach, explicit or implicit, was long intensely uncongenial to Russian specialists, who, in contrast, sought to "depoliticize" the study of literary texts (at least, that's what we thought we were doing). The terms and emphases of Anglo-American cultural studies also seemed wrong for Russia. How can the culture of the 
Communist world be studied in terms of capitalism and the nation-state, according to a paradigm that takes no account of command economies and party-states? (Condee 202).

Or perhaps a more flexible model of culture itself is needed. Lotman's notion of the semiosphere, the semiotic environment in which communication occurs, provides a more appealing foundation for the local investigations undertaken by Russian cultural studies. Lotman's semiosphere emphasizes shifting boundaries and hierarchies, complex interactions between the center and the periphery, mediations and translations, and unity through diversity. His work offers its deepest commitment to re-creating the past on its own terms as opposed to rendering a political critique of contemporary society (Schönle and Shine 28). This self-aware effort to see with past eyes also sheds light on the ongoing life of the past in the present.

Now we-like so many of our colleagues in fellow disciplines-work in broader temporal arcs, looking at the intersections of historical and cultural categories at various common "sites," struggles over symbolic capital, and the imperial and Soviet and post-Soviet search for a "usable" past. The post-Soviet period has inspired work on iconography and the deployment of official symbolic systems across the centuries: from 1812 through the Stalinist 1930s, World War II, and the 1990s. No scholar of culture can fail to be engrossed by the dramatic expression of imperial nostalgia in recent cultural production-the looming Tsereteli statue of Peter the Great on the Moscow River, the speedily re-created Church of the Savior, the reburial of the last Romanovs, the costly conversion of the derelict Strelna Palace into President Putin's base for highlevel international retreats, and the painstakingly reconstructed Amber Room (looted by the Nazis and taken away in pieces in the aftermath of war) at Tsarskoe Selo....

Recent Russian literary and cultural developments that inspire scholars to work in a decentering spirit that encompasses the globe include, to give only a few examples, the writing of younger bicultural and heritage speakers of Russian who do not live in Russia (Gary Shteyngart, Lara Vapnyar, David Bezmogis) and literature written in Russian by writers with allegiances to other cultures and languages (Andrey Volos, Sukhbat Aflatuni). Russian poetry is flourishing, as are Russian poetry studies. ${ }^{9}$ The Internet has had a genuinely democratizing effect on the literary life of Russian poets; their blogs, postings, and recorded readings are available online to all. And because so many poets writing in Russian travel, translate, and reside outside Russia, the paradigm of the national literary tradition is being transformed before our eyes, far more than it was by the Russian modernist emigration in 1920s and 1930s Europe.

Contemporary film studies too are thriving, as best evidenced perhaps by the international profile of directors such as Nikita Mikhalkov and Aleksey Balabanov and the changing conditions of Russian cinematic production (joint ventures and coproduction [Goscilo; see also Larsen, "National Identity"]). Seventy-fifth-anniversary events celebrating Andrey Tarkovsky's work are being staged around the world, and the contemporary directors Kira Muratova (The Asthenic Syndrome [1990] and Two in One [2007]) and Alexander Sokurov (Mother and Son [1996] and Russian Ark [2002]) continue to attract strong interest, as do documentary filmmakers such as Sergey Loznitsa. There have been several important post-Soviet films on Stalinism, notably Andrey Zvyagintsev's The Return (2003 [Strukov; see also Larsen, "Melodramatic Masculinity"]). A Web-based journal of reviews called KinoKultura, run by Birgit Beumers and Vladimir Padunov, helps us all keep up. The forces of distance, prohibition, and desire that formerly shaped our approach to Russian culture have given way to opportunities for contact and engagement that redefine our view of the past and our relation to our subject. 


\section{New Perspectives on Old Times}

Recent work on the revolutionary and early Soviet periods (1917-31) from the post-Soviet perspective emphasizes processes of negotiation and affinity rather than stark oppositions of party and writer. These new studies treat power in a more Foucauldian spirit, not as exerting brute force from above on passive citizens but as producing (rather than repressing) the Soviet people in complex and contradictory ways (Kiaer and Naiman 18). ${ }^{10}$ The relation between intellectuals and official Soviet power has also been revisioned as more ambiguous, even, in some cases, as symbiotic. Katerina Clark proposed a more central role taken by avant-garde intellectuals and a new account of the factors leading to Stalinism, charting complex affinities as part of "the ecology of revolution" and proposing a model of punctuated evolution that includes periods of adaptation and consolidation at least as important as the much documented cataclysms (Petersburg ix).

Soviet totalitarian studies are joining the larger history of identity formation in modernity, offering a trajectory different from but related to that of the West. The role of language and its relation to the physical body have assumed a particular importance here. Michael Gorham explores the Bolshevik's creation of a chaotic blend of neologisms (newspeak), high-Marxist terms, bureaucratese, and slang, as well as the reception of this discourse by the semiliterate peasants that constituted its primary audience (21). Eric Naiman proposes an "ideological poetics" of the New Economic Policy period (1921-28), a poetics in which ideological anxieties were projected onto a discourse about sex and the body (menstruation, anorexia, castration). Eliot Borenstein examines mythologies of an all-male utopian proletarian society that reject domesticity and the nineteenth-century-intelligentsia ideal of strong moral femininity.

Scholars have also turned their attention from familiar notions of resistance and heroic individuals to everyday lived experience, interior life, and ordinary practices. Jonathan Bolton develops a Lotmanian conception of everyday life as a "boundary" zone "in which individual practices and habits come into conflict with the codes and systems that a dominant discourse of the 'center' seeks to impose" (321). Bolton distinguishes Lotman's view of everyday life from that of Foucault (for whom everyday life is part of what is "disciplined") and Certeau (for whom everyday life is incapable of being captured in larger sign systems [330-33]). The everyday is thus a realm of circulation, translation, and contradiction, neither a site of resistance nor one of intensified manipulation.

Samizdat, or self-published texts, can now be read, in Serguei Oushakine's words, "through the discursive web of Soviet society within which they were conceived (or caught?) and whose traces they carried ("Terrifying Mimicry" 192; see also Komaromi, "Material Existence"). Analyzing the rhetoric of public political dissent in the Soviet Union suggests that resistance is not located outside the field of power (hidden underground), and that "the oppositional discourse of the dissident movement in the Soviet Union . . . echoed and amplified the rhetoric of the regime, rather than positioning itself outside of or underneath it" (192). From this perspective, samizdat emerges as hybrid text, constituted by authoritative discourse, but from a different direction, and to mixed effect. Power constrains and produces the subject, and censorship limits yet also activates the possibility of speech.

Approaches to the Stalinist period (193253) have shifted dramatically. Studies of this period, perhaps more than those of any other, used to be dominated by a moral stance, which documented the horrors of the Stalinist terror and the seemingly unilateral doctrine of socialist realism, "the truthful depiction of that which leads life toward socialism" (Kemp-Welch 131; see also 120-32). Yet Karen Petrone finds the discourse of Stalinist mass 
celebrations to be anything but totalizing, a field of fissures, multiple meanings, alternative and conflicting viewpoints, miscommunications, and compromise. (Of course, one might wonder at the seeming uniformity of our current preoccupation with uncovering multiplicity, but it can certainly be taken as a sign that this methodology has quickly met with broad acceptance in our discipline.)

The mid-1930s have generally been seen as constituting a sharp break with the radical experiments and cultural pluralism of the preceding period, a turn back to more conventional cultural norms and a sacralization of the state evident above all in the cult of Stalin. ${ }^{11}$ Recent scholarship emphasizes continuities as well as abrupt reversals, looking at the ways in which Stalinist policies continued the revolutionary project of creating a new Soviet person who lived by socialist values. These studies examine norms governing morality, family, education, leisure, and hygiene and investigate collective cultural sites such as the Soviet-era communal apartment, but they also consider what Svetlana Boym calls "everyday aesthetic experiences and alternative spaces carved between the lines and on the margins of the official discourses" (5; see also Fitzpatrick). Alexei Yurchak argues that "living" socialism - a system of human values and an everyday reality of life-carried personal meanings quite different from official state rhetoric, meanings related to ethics, friendships, and creative altruism (8). In part, post-Soviet nostalgia connects with a sense of loss around these values, reflecting the ambivalent ways in which former Soviet citizens view their collective past.

Even socialist realism has become more interesting. ${ }^{12}$ Boris Groys argues provocatively that Stalinist art and literature corresponded in many respects to the earlier project of the Russian avant-garde, that Stalinism actually continued the avant-garde project in a spirit of even greater radicalism, seeking to transform society according to aesthetico-political prin- ciples in an artistic experiment on an unprecedented scale (Total Art). ${ }^{13}$ Yet socialist realism now seems less a monolith than an aesthetic that extended across historical moments and geographic divides, to remote republics of the former Soviet Union, to China, France, even the United States, taking shape in diverse genres and causing a range of critical discourses to spring up in response to it (Lahusen and Dobrenko). Evgeny Dobrenko asserts that socialist realism was not simply invented and handed down by the cultural and political authorities but created collaboratively, as a hybrid, through a negotiation between those in power and the masses ("Disaster"). And despite socialist realism's purported unity of method, scholars now find in the aesthetic a diversity of styles, fragments of the multiple defunct projects from the revolutionary era, now seeing socialist realism as a synthetic doctrine. Groys characterizes socialist realism as a "style and a half," a protopostmodernism that appropriated forms such as folk art and mass culture but was akin to modernism in its claims to autonomy from commercial culture ("Style"). Interest in Soviet style has also extended to the Soviet "grand style" and to "sots art" (late Soviet pop art), the latter making playful or ironic use of Soviet ideological clichés. Totalitarianism commodified culture and ideas no less than did Western political systems, it turns out.

\section{Late Soviet, Post-Soviet, and Postmodernist Soviet}

Is it possible to speak of postmodernism in Russia, and if so, how do the terms of engagement shift when the situation is not late capitalist? Mikhail Epstein has characterized post-Soviet Russia as "postfuturis[t]," since "the 'communist future' has become a thing of the past, while the feudal and bourgeois 'past' approaches us from the direction where we had expected to meet the future" (After the Future xi). Although the discourse of postmodernism originated in the West in the 
early 1970s and in Russia not until the early 1990 s, Russia is "innately" postmodern, perhaps even the true "birthplace" of postmodernism, if postmodernism means the absence of any reality other than the reality of ideas (Epstein, "Postmodernism" 28).

The late Soviet period (from Brezhnev onward, 1960s-80s) seems perhaps ripest for revisioning, especially the years of "stagnation" (Застой), a term applied retrospectively during perestroika. Alexei Yurchak declares the fall of the Soviet Union to have been both unimaginable and unsurprising, tracing the moment of change back to the 1950s, when the "external metadiscourse on ideology" disappeared, resulting in a "hypernormalization" of ideological discourse: "the performative reproduction of the form of rituals and speech acts actually enabled the emergence of diverse, multiple, and unpredictable meanings in everyday life, including those that did not correspond to the constative meanings of authoritative discourse" (25). Perestroika began as a deconstruction of authoritative Soviet discourse and then reintroduced the lost element of public metacommentary on authoritative discourse. ${ }^{14}$

There has also been a great deal of interest in describing the unique sociocultural situation of the first postsocialist generation in Russia, whose immediate environment nevertheless bears significant traces of Soviet life. "Post-Soviet aphasia" refers to a discourse in which complex usage of older symbolic forms compensates for the lack of new creative symbolic production; this discourse is symptomatic of inadequate post-Soviet interpellation. The post-Soviet was perceived as an empty space, a nonexistence, a culture of symbolic shortages (Oushakine, "In the State"). And the behavior of the Soviet consumer, rooted in the economy of shortages, continues to shape the post-Soviet understanding of consumption. (This behavior has been described as filling up imagined new grocery bags with the same old sausage, perhaps in a better wrapping, with better service [Oushakine, "Quantity"].) In this sense, post-Soviet studies can still be considered studies of the Soviet Union, since so many old habits of thought and terms of engagement have persisted, both in our objects of study and in our research practices. The afterlife of the Soviet period is not just something we study-it is a part of us.

Cultural anthropology has in many respects led the way for all disciplines engaged with the postsocialist sphere, encouraging us to think in terms of hybrid societies rather than polar extremes, in terms of the microworld of everyday life rather than the macrostructures of state and economy (Burawoy and Verdery). Unintended consequences occur locally as a result of political and cultural contestation intertwined with economic struggles. Responses to new situations use language and symbols adapted from previous orders; familiar forms are used with new meanings and to new ends. Cultural anthropology offers us models for studying local languages and discourses, markets, contested memories and histories of trauma, and coping strategies (Ries).

Russian studies today offer a field of decentering, unraveling, plural projects. We have a sense of many overlapping topics in the layering of premodern, imperial, Soviet, and post-Soviet cultural spaces. We examine contradictory trajectories of renaming and reclaiming, looting and restoration. This larger project is not Pan-Slavic-a nineteenthcentury notion whereby Russia thought to decide what was best for all the Slavs-but Trans-Slavic, not merely in moving across formerly separate fields in the course of our investigations but in rising up into the heady atmosphere of a larger cultural and historical perspective than ever before, coming at the old maps from new angles, working simultaneously in multiple contexts. Our discipline comes by these more capacious perspectives naturally. Russia still fascinates us as the vivid, maddeningly maximalist place it has always been. Whatever may have changed, 
Western specialists still revel in the pleasures of studying this cultural space, marked by wild ideas that were taken seriously, excesses, chaos, and freakishly brilliant achievements.

\section{NOTES}

My thanks go to those who read drafts of this essay and helped me shape it-Jonathan Bolton, Julia Bekman Chadaga, Lisa Rodensky, Stephanie Sandler, and Justin Weir.

1. Engelstein writes, "In the 1990 s, when historians turned their attention to the nature of the judicial reforms and the operation of Imperial legal institutions, they echoed the interests of post-Soviet Russian society, concerned with establishing a viable legal order as the basis for democratic government and a market economy" ("New Thinking" 491).

2. In Aleksander Solzhenitsyn's famous phrasing, from his 1968 novel The First Circle, literature constituted a "second government" in Russia, exerting its moral force on citizens and public officials alike (415).

3. Stalin took up this phrase in preparation for the imminent adoption of socialist realism as the literary doctrine mandated by the state and for the first congress of the Union of Soviet Writers, in 1934. The phrase was used prominently in speeches at this congress (Kemp-Welch 131).

4. See, for example, Sandler, Commemorating Pushkin. See also Kelly, who constructs a picture of modern Russian literature out of central notions unpacked from a single short lyric by Pushkin.

5. On questions of homogenization and multiple nationalisms, see Slezkine.

6. The answer seems to be a decided yes. See Beissinger; Bugajski; Hirsch.

7. Note Ram's critique of Eurasia as "an indeterminate category with an uneven history of discursive elaboration" and a paradoxical concept (832-33).

8. Jeffrey Brooks's, When Russia Learned to Read: Literacy and Popular Culture, 1861-1917 (1985) was a pioneering study in this regard. For more recent scholarship, see McReynolds.

9. In 2007, the American Association of Teachers of Slavic and East European Languages awarded its Literary and Cultural Studies Book Prize to a poetry study: Cathy Ciepiela's The Same Solitude: Boris Pasternak and Marina Tsvetaeva. For another excellent recent study, see MacKay. Sandler provides a good overview of changing paradigms (Introduction).

10. See also Stephen Kotkin's Magnetic Mountain: Stalinism as a Civilization, the first Western monograph to provide a social history of the Stalinist period whose author had full access to local archives. Other important sources on this topic include Halfin; Hellbeck.
11. For a close and critical examination of this turn back to the imperial past, see Platt and Brandenberger.

12. Katerina Clark's The Soviet Novel (1981) was the first piece of Western scholarship to take up the virtually taboo topic of socialist realism.

13. This approach represented a shift from that of Vladimir Paperny's Architecture in the Age of Stalin: Culture Two (1985), which viewed socialist realism ("culture two") as the polar opposite of 1920 avant-garde ("culture one") and as transforming the latter's horizontal, plural spatial organization into a vertical, centralized model.

14. For a recent account of unofficial culture and dissident social activity during the post-Stalin period, see Komaromi, "Unofficial Field."

\section{Works CONSUlted}

Barker, Adele Marie, ed. Consuming Russia: Popular Culture, Sex, and Society since Gorbachev. Durham: Duke UP, 1999. Print.

Beissinger, Mark R. "The Persistence of Empire in Eurasia." NewsNet 48.1 (2008): 1-8. Print.

Berry, Ellen E., and Mikhail N. Epstein. Transcultural Experiments: Russian and American Models of Creative Communication. New York: St. Martin's, 1999. Print.

Bolton, Jonathan. "Writing in a Polluted Semiosphere: Everyday Life in Lotman, Foucault, and de Certeau." Schonle 320-44.

Borenstein, Eliot. Men without Women: Masculinity and Revolution in Russian Fiction, 1917-1929. Durham Duke UP, 2000.

Boym, Svetlana. Common Places: Mythologies of Everyday Life in Russia. Cambridge: Harvard UP, 1994. Print.

Brooks, Jeffrey. When Russia Learned to Read: Literacy and Popular Culture, 1861-1917. Princeton: Princeton UP, 1985. Print.

Buckler, Julie. Mapping St. Petersburg: Imperial Text and Cityshape. Princeton: Princeton UP, 2005. Print.

Buck-Morss, Susan. Dreamworld and Catastrophe: The Passing of Mass Utopia in East and West. Cambridge: MIT P, 2000. Print.

Bugajski, Janusz. Cold Peace: Russia's New Imperialism. Westport: Praeger, 2004. Print.

Burawoy, Michael, and Katherine Verdery. Uncertain Transition: Ethnographies of Change in the Postsocialist World. Lanham: Rowman, 1999. Print.

Chernetsky, Vitaly, Nancy Condee, Harsha Ram, and Gayatri Chakravorty Spivak. "Are We Postcolonial? Post-Soviet Space." "Forum: Conference Debates." PMLA 121.3 (2006): 828-36. Print.

Churchill, Winston S. The Gathering Storm. Boston: Houghton, 1985. Vol. 1 of The Second World War. Google Book Search. Web. 13 Feb. 2009. 
Ciepiela, Cathy. The Same Solitude: Boris Pasternak and Marina Tsvetaeva. Ithaca: Cornell UP, 2006. Print.

Clark, Katerina. "Beyond the Wall, and All That: AAASS Moves toward the Twenty-First Century." NewsNet 40.1 (2000): 1-8. Print.

- Petersburg: Crucible of Cultural Revolution. Cambridge: Harvard UP, 1995. Print.

- The Soviet Novel: History as Ritual. Chicago: U of Chicago P, 1981. Print.

Condee, Nancy. "Drowning or Waving? Some Remarks on Russian Cultural Studies." Slavic and East European Journal 50.1 (2006): 197-203. Print.

Dobrenko, Evgeny. "The Disaster of Middlebrow Taste; or, Who 'Invented' Socialist Realism?" Lahusen and Dobrenko 135-64.

Emerson, Caryl. "Literary Humility: The Case of Russia under Its Old Regimes." Common Knowledge 8.3 (2002): 482-95. Print.

_ . "Slavic Studies in a Post-communist, Post 9/11 World: For and against Our Remaining in the Hardcore Humanities." Slavic and East European Journal 46.3 (2002): 449-64. Print.

Engelstein, Laura. The Keys to Happiness: Sex and the Search for Modernity in Fin-de-Siècle Russia. Ithaca: Cornell UP, 1992. Print.

. "New Thinking about the Old Empire: Post-Soviet Reflections." Russian Review 60 (2001): 487-96. Print.

__. "Paradigms, Pathologies, and Other Clues to Russian Spiritual Culture: Some Post-Soviet Thoughts." Slavic Review 57.4 (1998): 864-77. Print.

Epstein, Mikhail. After the Future: The Paradoxes of Postmodernism and Contemporary Russian Culture. Amherst: U of Massachusetts P, 1995. Print.

__. "Postmodernism, Communism, and Sots-Art." Endquote: Sots-Art Literature and Soviet Grand Style. Ed. Marina Balina, Nancy Condee, and Evgeny Dobrenko. Evanston: Northwestern UP, 2000. 3-31. Print.

_. "Transculture and Society." Berry and Epstein 102-12.

Fitzpatrick, Sheila. Everyday Stalinism: Ordinary Life in Extraordinary Times: Soviet Russia in the 1930s. New York: Oxford UP, 1999. Print.

Gheith, Jehanne M. Finding the Middle Ground: Krestovskii, Tur, and the Power of Ambivalence in Nineteenth-Century Russian Women's Prose. Evanston: Northwestern UP, 2004. Print.

Gorham, Michael S. Speaking in Soviet Tongues: Language Culture and the Politics of Voice in Revolutionary Russia. DeKalb: Northern Illinois UP, 2003. Print.

Goscilo, Helena. Introduction. "Resent, Reassess, and Reinvent: The Three R's of Post-Soviet Cinema." Slavic and East European Journal 51.2 (2007): 213-28. Print.

Groys, Boris. "A Style and a Half: Socialist Realism between Modernism and Postmodernism." Lahusen and Dobrenko 76-90.
- The Total Art of Stalinism: Avant-Garde, Aesthetic Dictatorship, and Beyond. Trans. Charles Rougle. Princeton: Princeton UP, 1992. Print.

Halfin, Igal. Terror in My Soul: Communist Autobiographies on Trial. Cambridge: Harvard UP, 2003. Print.

Hanson, Stephen E., and Blair A. Ruble. "Rebuilding Russian Studies.” Problems of Post-communism 52.3 (2005): 49-57. Print.

Hellbeck, Jochen. Revolution on My Mind: Writing a Diary under Stalin. Cambridge: Harvard UP, 2006. Print.

Hirsch, Francine. Empire of Nations: Ethnographic Knowledge and the Making of the Soviet Union. Ithaca: Cornell UP, 2005. Print.

Holquist, Michael. "Corrupt Originals: The Paradox of Censorship." Introduction. Literature and Censorship. Spec. issue of PMLA 109.1 (1994): 14-25. Print.

Kappeler, Andreas. The Russian Empire: A Multiethnic History. Trans. Alfred Clayton. New York: Longman, 2001. Print.

Kelly, Catriona. Russian Literature: A Very Short Introduction. Oxford: Oxford UP, 2001. Print.

Kemp-Welch, A. Stalin and the Literary Intelligentsia, 1928-39. Basingstoke: Macmillan, 1991. Print.

Kiaer, Christina, and Eric Naiman. Everyday Life in Early Soviet Russia: Taking the Revolution Inside. Bloomington: Indiana UP, 2006. Print.

Komaromi, Ann. "The Material Existence of Soviet Samizdat." Slavic Review 63.3 (2004): 597-618. Print.

_. "The Unofficial Field of Late Soviet Culture." Slavic Review 66.4 (2007): 605-29. Print.

Kotkin, Stephen. Magnetic Mountain: Stalinism as a Civilization. Berkeley: U of California P, 1995. Print.

Kujundzic, Dragan. “The Future of Slavic Studies.” AATSEEL Newsletter 45.2 (2002): 5-6. Print.

Lahusen, Thomas, and Evgeny Dobrenko, eds. Socialist Realism without Shores. Durham: Duke UP, 1997. Print.

Larsen, Susan. "Melodramatic Masculinity, National Identity, and the Stalinist Past in Post-Soviet Cinema." Studies in 20th-Century Literature 24.1 (2000): 85-120. Print.

—. "National Identity, Cultural Authority, and the Post-Soviet Blockbuster: Nikita Mikhalkov and Aleksei Balabanov." Slavic Review 62.3 (2003): 491-511. Print.

Lotman, Iurii M., and Boris A. Uspensky. "Binary Models in the Dynamics of Russian Culture (to the End of the Eighteenth Century)." The Semiotics of Russian Cultural History. Ed. Alexander D. Nakhimovsky and Alice Stone Nakhimovsky. Ithaca: Cornell UP, 1985. 31-33. Print.

Lovell, Stephen. The Russian Reading Revolution: Print Culture in the Soviet and Post-Soviet Eras. New York: St. Martin's, 2000. Print.

MacKay, John. Inscription and Modernity: From Wordsworth to Mandelstam. Bloomington: Indiana UP, 2006. Print. 
Malia, Martin. “The Russian Riddle." Introduction. Russia under Western Eyes: From the Bronze Horseman to the Lenin Mausoleum. Cambridge: Harvard UP, 1999. 1-14. Print.

Marks, Steven G. How Russia Shaped the Modern World: From Art to Anti-Semitism, Ballet to Bolshevism. Princeton: Princeton UP, 2003. Print.

McDaniel, Tim. The Agony of the Russian Idea. Princeton: Princeton UP, 1996. Print.

McReynolds, Louise. Russia at Play: Leisure Activities at the End of the Tsarist Era. Ithaca: Cornell UP, 2003. Print.

Moore, David Chioni. "Is the Post- in Postcolonial the Post- in Post-Soviet? Toward a Global Postcolonial Critique.” PMLA 116.1 (2001): 111-28. Print.

Naiman, Eric. Sex in Public: The Incarnation of Early Soviet Ideology. Princeton: Princeton UP, 1997. Print.

Nepomnyashchy, Catherine Theimer, Nicole Svobodny, and Ludmilla A. Trigos, eds. Under the Sky of My Africa: Alexander Pushkin and Blackness. Evanston: Northwestern UP, 2006. Print.

Olcott, Anthony. Russian Pulp: The Detektiv and the Russian Way of Crime. Lanham: Rowman, 2001. Print.

Oushakine, Serguei. "In the State of Post-Soviet Aphasia: Symbolic Development in Contemporary Russia." Europe-Asia Studies 52.5 (2000): 991-1016. Print.

. "The Quantity of Style: Imaginary Consumption in the New Russia." Theory, Culture, and Society 17.5 (2000): 97-120. Print.

_ . "The Terrifying Mimicry of Samizdat." Public Culture 13.2 (2001): 191-214. Print.

Paperny, Vladimir. Architecture in the Age of Stalin: Culture Two. Trans. John Hill and Roann Barris. Cambridge: Cambridge UP, 2002. Print.

Parthé, Kathleen F. Russia's Dangerous Texts: Politics between the Lines. New Haven: Yale UP, 2004. Print.

Peterson, Dale E. Up from Bondage: The Literatures of Russian and African American Soul. Durham: Duke UP, 2000. Print.

Petrone, Karen. Life Has Become More Joyous, Comrades: Celebrations in the Time of Stalin. Bloomington: Indiana UP, 2000. Print.

Platt, Kevin M. F. "Will the Study of Russian Literature Survive the Coming Century? A Provocation." Slavic and East European Journal 50.1 (2006): 204-12. Print.

Platt, Kevin M. F., and David Brandenberger, eds. Epic Revisionism: Russian History and Literature as Stalinist Propaganda. Madison: U of Wisconsin P, 2006. Print.

Poe, Marshall T. The Russian Moment in World History. Princeton: Princeton UP, 2003. Print.

Ram, Harsha. "Between 1917 and 1947: Postcoloniality and Russia-Eurasia." "Forum: Conference Debates." PMLA 121.3 (1996): 831-33. Print.

Ries, Nancy. "Anthropology and Eurasia: Why Culture Matters in the Study of Postsocialism." NewsNet 45.4 (2005): 1-5. Print.
Safran, Gabriella. Rewriting the Jew: Assimilation Narratives in the Russian Empire. Stanford: Stanford UP, 2000. Print.

Sandler, Stephanie. Commemorating Pushkin: Russia's Myth of a National Poet. Stanford: Stanford UP, 2004. Print.

- Introduction. Rereading Russian Poetry. Ed. Sandler. New Haven: Yale UP, 1999. 1-27. Print.

Schenker, Alexander M. "What's in a Name? The Linguistic and Cultural Boundaries of AATSEEL." Slavic and East European Journal 50.1 (2006): 3-11. Print.

Schönle, Andreas, ed. Lotman and Cultural Studies: Encounters and Extensions. Madison: $\mathrm{U}$ of Wisconsin $\mathrm{P}$, 2006. Print.

Schönle, Andreas, and Jeremy Shine. Introduction. Lotman and Cultural Studies: Encounters and Extensions. Schonle 3-35.

Slezkine, Yuri. "The USSR as a Communal Apartment; or, How a Socialist State Promoted Ethnic Particularism." Slavic Review 53.2 (1994): 414-52. Print.

Solzhenitsyn, Aleksander. The First Circle. Trans. Thomas P. Whitney. New York: Harper, 1968. Print.

Steiner, Peter. "Slavic Literary Studies Yesterday and Tomorrow." Profession (1987): 2-9. Print.

Stites, Richard, ed. Culture and Entertainment in Wartime Russia. Bloomington: Indiana UP, 1995. Print.

_. Russian Popular Culture: Entertainment and Society since 1900. Cambridge: Cambridge UP, 1992. Print.

Strukov, Vladimir. "The Return of Gods: Andrei Zviagintsev's Vozvrashchenie (The Return)." "Resent, Reassess, and Reinvent: The Three R's of Post-Soviet Cinema." Slavic and East European Journal 51.2 (2007): 331-56. Print.

Thompson, Ewa M. Imperial Knowledge: Russian Literature and Colonialism. Westport: Greenwood, 2000. Print.

Todd, William Mills, III. "On the Care and Development of 'Home-Grown Disciplines."' Slavic and East European Journal 51.1 (2007): 1-15. Print.

_. "Russian Literature: Projects for the Future." Stanford Humanities Review 6.1 (1998): 26-40. Print.

Todorova, Maria. Imagining the Balkans. New York: Oxford UP, 1997. Print.

Verdery, Katherine. "What's in a Name, and Should We Change Ours?" NewsNet 46.2 (2006): 1-4. Print.

von Hagen, Mark. "Empires, Borderlands, and Diasporas: Eurasia as Anti-paradigm for the Post-Soviet Era." American Historical Review 109.2 (2004): 445-68. Print.

Wachtel, Andrew Baruch. Remaining Relevant after Communism: The Role of the Writer in Eastern Europe. Chicago: U of Chicago P, 2006. Print.

Wolff, Larry. Inventing Eastern Europe: The Map of Civilization on the Mind of the Enlightenment. Stanford: Stanford UP, 1994. Print.

Yurchak, Alexei. Everything Was Forever, until It Was No More: The Last Soviet Generation. Princeton: Princeton UP, 2006. Print. 